This item was submitted to Loughborough's Research Repository by the author.

Items in Figshare are protected by copyright, with all rights reserved, unless otherwise indicated.

\title{
Two kinds of natural
}

PLEASE CITE THE PUBLISHED VERSION

http://dx.doi.org/10.1177/14614456020040040901

PUBLISHER

(c) Sage

VERSION

AM (Accepted Manuscript)

LICENCE

CC BY-NC-ND 4.0

REPOSITORY RECORD

Potter, Jonathan. 2019. "Two Kinds of Natural". figshare. https://hdl.handle.net/2134/15081. 
This item was submitted to Loughborough's Institutional Repository (https://dspace.lboro.ac.uk/) by the author and is made available under the following Creative Commons Licence conditions.

\section{creative
commons}

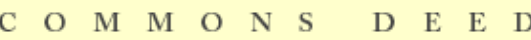

Attribution-NonCommercial-NoDerivs 2.5

You are free:

- to copy, distribute, display, and perform the work

Under the following conditions:

Attribution. You must attribute the work in the manner specified b the author or licensor.

Noncommercial. You may not use this work for commercial purposes.

No Derivative Works. You may not alter, transform, or build upon this work.

- For any reuse or distribution, you must make clear to others the license terms of this work.

- Any of these conditions can be waived if you get permission from the copyright holder.

Your fair use and other rights are in no way affected by the above.

This is a human-readable summary of the Leqal Code (the full license).

\section{Disclaimer 만}

For the full text of this licence, please go to: http://creativecommons.org/licenses/by-nc-nd/2.5/ 


\section{TWO KINDS OF NATURAL}

\section{JonATHAN PotTer}

Discourse and Rhetoric Group

Department of Social Sciences

Loughborough University

Loughborough

Leicestershire, LE11 3TU
Email: J.A.Potter@lboro.ac.uk

Tel: 01509223384

Fax: 01509223944

Published as:

Potter, J. (2002). Two kinds of natural, Discourse Studies, 4, 539-542. 
Sue Speer (in press) has done discourse researchers a favour by focusing interest on issues to do with status of data and the various ways in which notions of 'contrived', 'natural', 'naturalistic' and so on have been used. She helpfully highlights a range of different issues and complexities, and identifies some apparent inconsistencies. It is right that more explication goes on in this area. Nevertheless, I believe that what appear to be inconsistencies arise mainly from discourse researchers using the notions to do two rather different jobs.

Specifically, the contrived/natural distinction has been used to highlight a preference for materials that are not 'got up' or produced for a specific research task. At the same time, discourse and conversation researchers are well aware of the limited sense of natural being developed here, and have offered cautions to that effect. They have also noted that it is possible to naturalise the interaction in an experiment, questionnaire or focus group; that is, treat it as a topic for interactional study. Yet treating method as topic is not the same as using it to find something out. Let me consider these points in a little more detail.

\section{THE CONTRIVED/NATURAL DISTINCTION}

The value of this distinction is that it highlights something about most social science (especially in sociology and psychology) which is that it has developed using material, data, that is got up specifically for the research enterprise. I do not see this as an injunction to find data that is 'unbiased' - that would be a very traditional notion of data and purity. Rather I see it as highlighting the researcher's central place in the production of conventional research data, and highlighting the virtue of material where the researchers active role is minimized. Traditionally this is material was previously seen as defying systematic research. This assumption was most famously enshrined in Chomsky's suggestion that researchers can only 
consider underlying linguistic competence because the actual performance of talk is impossibly unique and messy. Psychologists have been some of the last researchers to recognise the value of studying interactional material without first coding it and counting it. Conversation analysts and, more recently, discursive psychologists have shown just how effective working with natural materials can be.

There are a number of longstanding critiques of data generated in experiments and other structured methods. However, discursive psychologists often point to one or more of the following five virtues of natural talk.

1) It does not flood the research setting with the researcher's own categories (embedded in questions, probes, stimuli, vignettes and so on);

2) It does not put people in the position of disinterested experts on their own and other's practices, thoughts and so on, encouraging them to provide normatively appropriate descriptions (as many interview and questionnaire studies do);

3) It does not leave the researcher to make a range of more of less problematic inferences from the data collection arena to topic (from interviews about counselling, say, to counselling itself) as the topic itself (counselling, perhaps) is directly studied;

4) It opens up a wide variety of novel issues and concerns that are outwith the prior expectations embodied in questionnaires, experimental formats, interviews questions and so on;

5) It is a rich record of people living their lives, pursuing goals, managing institutional tasks and so on.

None of these points, in themselves, show that interviews or experiments cannot be useful or revealing. However, they suggest that the justificatory boot might be better placed 
on the other foot. The question is not why should we study natural materials, but why should we not?

\section{A LIMITED NATURAL}

In spite of the above, Speer is quite right to point out, as others have done, that the notion of natural here is a rather limited one. In studies of natural talk, data is typically collected from research participants who have provided informed consent, are aware of the recording, and may consequently modify their actions in a range of ways. And as Speer notes, there are a range of practical, analytic and theoretical ways of managing these problems (sometimes talked of in terms of reactivity). In addition, sociologists of scientific knowledge and semiologists of various kinds have undercut traditional expectations about the independent and timeless nature of what is seen as natural. The idea of natural data as marking out a particular ontological realm in a simple way is certainly flawed.

My suggestion has been to mark these problems linguistically by writing of naturalistic rather than natural data. This allows us as researchers to mark the useful contrast between data that is got up and data that is, at least ideally, not, while recognising the limits on that distinction. Another way into this is to avoid the troubling term 'natural' and focus on the issue of researcher agency. As Speer notes, I have suggested a (conceptual) dead social scientists test - would the data be the same, or be there at all, if the researcher got run over on the way to work? An interview would not take place without the researcher there to ask the questions; a counselling session would whether the researcher turns up to collect the recording or not. 


\section{NATURALISING Methods INTERACTION}

Speer highlights work by conversation analysts and discursive psychologists that takes method as its topic - the interaction in a structured survey, say, or a focus group. She takes from this that anything that can be studied can be naturalised, and that this breaks down the contrived/natural distinction. While this is an important point, I do not think it blunts the force of the distinction.

Take the study Claudia Puchta and I did of questions in focus groups (Puchta \& Potter, 1999). This took as its topic records of interaction in focus groups, and in particular the ways questions are designed and the interactional consequences of different designs. However, doing this did not involve endorsing (or, indeed, criticising) the use of focus groups to study particular questions. This study had a quite different objective, which was to consider how a bit of social research practice gets done. Put simply, the possibility of studying how a particular bit of social research is contrived does not show that the contrived/natural distinction is not useful.

Taking a naturalistic stance to a social research method is very different from using that method to do research. Traditional interview studies are not focused on their interactional organization; they are drawing on a research procedure that is taken to generate interesting data. Typically, the more this data is seen as an interactional product the less interesting it is seen to be. That is not to say that important studies have not been done using interview material (Speer cites several). However, even when naturalised for study, their status as got up by the researcher is still something to be grappled with. 


\section{CONCLUSION}

These are complicated issues and Speer has done a useful job highlighting some of their convolutions. However, I think that the conceptualisation in this area has been rather more coherent than Speer allows. While there are limits to the notion of naturalistic data, this does not mean that it is much the same sort of thing as focus group, interview or experimental interaction. There is a world of difference between the material gathered in a questionnaire from the record of an everyday phone conversation; what is gained by studying a video of a family therapy session is very different from the retrospective accounts of participants. If anything, one of the successes of work in discourse and conversation analysis been in showing up just how complex and subtle researcher guided interaction in interviews, focus groups and other research arenas is. Studies of questionnaires and focus groups have highlighted the delicate ways in which the researcher generates countable findings or conventional social science objects such as attitudes (e.g. Antaki, et al., 2000; Puchta \& Potter, in press). The distinction may be rather more complex than previously thought, but the points it is used to make are no less important. 


\section{REFERENCES}

Antaki, C., Houtkoop-Steentra, H. \& Rapley, M. (2000). “Brilliant. Next Question...”: High-grade assessment sequences in the completion of interactional units, Research on Language and Social Interaction, 33, 235-262.

Puchta, C. \& Potter, J. (1999). Asking elaborate questions: Focus groups and the management of spontaneity, Journal of Sociolinguistics, 3, 314-35.

Puchta, C. \& Potter, J. (in press). Manufacturing individual opinions: Market research focus groups and the discursive psychology of attitudes, British Journal of Social Psychology.

Speer, S. (in press). 'Natural' and 'contrived' data: A sustainable distinction? Discourse Studies. 